\title{
Die vertellersperspektief-analise. 'n Literatuurteoretiese benadering in die eksegese van die evangelies
}

\author{
AG van Aarde
}

\section{INLEIDING}

\subsection{Vertrekpunt: die noodsaak van genre-identifisering}

Die belangrikste uitgangspunt in die eksegese van enige gedeelte in die Bybel is die oortuiging dat die aard van die genre wat die gedeelte verteenwoordig, die eksegetiese benadering bepaal. "Genre" is, breedweg gesien, 'n kollektiewe kategorie van literêre eenhede wat gemeenskaplike karaktertrekke in vorm en inhoud vertoon. Met die uitdrukking "literêre eenhede" bedoel ons hier nie die kleinere "vorme" (Gattungen) wat binne 'n geheel-konteks kan voorkom nie, maar juis die "teks as geheel" - die "holistiese konteks". "Genre" as die "holistiese konteks" is in die raamwerk van ons onderhawige interesse, dieselfde as die poëtiek van 'n teks, dit wil sê die wyse waarop "n teks "gemaak", oftewel "aanmekaar gesit" is. (Die herkoms van die woord "poëtiek" is geleë in die Griekse poieîn = om te maak.)

\section{2 'n Evangelie is die produk van die literêre aktiwiteit van 'n redaktor-verteller}

Die genre "evangelie" is vertelling. Die mees elementêre verskynsels wat die essensie van 'n "vertelling" uitmaak, is in die "evangelievorm" aanwesig. En dit is naamlik 'n verhaal, 'n verteller en 'n tipe leser. Die evangelies is egter nie die produk van die verbeelding (fiksie) nie. Met behulp van onder andere oorgelewerde tradisies, op 'n herinterpreterende en skeppende wyse redaksioneel verwerk, kommunikeer die evangeliste respektiewelik hulle eie teologiese idee deur middel van die verhaalvorm, soos storie-vertellers.

\subsection{Elke evangelie is 'n geslote "vertelde wêreld"}

Sodra 'n vertelling geskryf is, staan die teks los van sy historiese skrywer en funksioneer dit as 'n geslote vertelde wêreld met sy eiesoortige argitektoniese ontwerp met intrinsieke harmonieuse kenmerke. Die "geslote wêreld" van 'n vertelling bestaan uit 'n boodskap wat die skrywer as die sender deur middel van'n verteller aan 'n leser 
as die ontvanger kommunikeer. Die "boodskap" word oorgedra deur middel van die vertel van veral karakters wat in tyd en ruimte beweeg en wat plot (kyk later) konstitueer. In die interpretasie van verteltekste gaan dit nie soseer om die deurdring na die werklike wêreld van die historiese skrywer, plek en omstandighede van skrywe of dié van die historiese leser, plek en omstandighede van ontvangs nie. Dit gaan ook nie om die beskrywing van die vroeëre skriftelike of voor-skriftelike kontekstualiserings van 'n vertelling se tradisies nie. Die interpretasie van verteltekste is met ander woorde nie diakronies bepaald nie, maar sinkronies. Dit gaan om die interpretasie van die vertelde wêreld wat die skrywer deur middel van die verteller geskep het en waarin hy die vertelde karakters en tyds- en topografiese besonderhede bepaalde funksionele rolle laat vervul. Die feit dat ' $n$ evangelie referensieel na 'n binnetekstuele "vertelde wêreld" verwys, hoef egter nie 'n akroniese teksinterpretasie, soos dit in die algemeen binne die Strukturalisme die geval is, te impliseer nie. Hoewel die "vertelde wêreld" binnetekstueel na die "werklikheid" van die teks self verwys, sluit die "werklikheid" van die teks wel die sosio-politiese, ekonomiese en godsdienstige konteks van die tyd in toe die teks (in die geval van die evangelie, finaal) ontstaan het. Hierdie "historiese" omstandighede besit hermeneutiese relevansie egter alleen in die mate waarin dit in die teks self manifesteer.

Die voorafgaande betoog hou in dat ons in die interpretasie van die evangelies intentional fallacy, sowel as referential fallacy vermy. Met "intentional fallacy" word die oordeelsfout aangedui wat die eksegeet maak as hy reken dat hy sonder meer vanaf die vertelteks na die intensie van die skrywer as ' $n$ psigologiese persoonlikheid kan beweeg. Dieselfde geld wat die intensie van die historiese (eerste) lesers betref. Die intensie (perspektief-we) van die historiese skrywer en lesers word alleen verken deur 'n ondersoek na die wyse (tegnieke) waarop 'n skrywer, in sy kommunikasie aan lesers, sy vertelling aanbied. Dit geskied egter nie deur 'n ondersoek na die "werklike wêreld" as sodanig waarin die evangelis hom sou bevind het, soos byvoorbeeld die veronderstelde historiese situasie ("Sitz im Leben") van ò die evangelis self of sy lesers nie. Met "referential fallacy" word die fout aangedui wanneer die eksegeet uit die evangelie se "vertelde wểreld" sonder meer reglynig die "werklike wêreld" in 'n een-tot-een-verhouding wil aflees. Indien dit gebeur, neem die eksegeet nie in ag dat die gegewenhede in 'n vertelling vanuit die perspektief(-we) van die skrywer-verteller waargeneem, geëvalueer en aangebied is nie. Die problematiek met betrekking tot die verhouding tussen "betekenis" en "referensie" in 'n vertelteks, dit wil sê tussen "vertelde wểreld" en "werklike wêreld", en die hermeneutiese implikasies van dié problematiek, is ' $n$ uiters komplekse aangeleentheid en ook nie sommerso oplosbaar nie. In 'n sekere sin is 
hierdie vraagstuk die basiese probleem waaromtrent dit in die hermeneutiek gaan.

\subsection{Die "narrative point of view"-analise}

Die "wêreld" van 'n vertelteks is breedweg gesien, opgebou uit die interrelasies tussen die skrywer en die verteller; tussen die verteller en die (implisiete/geïdealiseerde) leser; tussen die verteller en die vertelde karakters; tussen die (implisiete/geïdealiseerde) leser en die vertelde karakters en tussen die vertelde karakters onderling in hulle binêre verhoudinge. Al hierdie interrelasies het te make met die wyse waarop 'n skrywer sy vertelling aanbied (struktureer). Die uitdrukking "wyse van aanbieding" word in die literatuurteorie, wat bekendstaan as "narrative point of view"-analise, met die tegniese term point of view weergegee.

Ten spyte van die substansiële aandag wat literêr-teoretici in hierdie eeu aan die literatuurteoretiese benadering "narrative point of view"-analise gegee het, is dit steeds 'n teorie waarvan die definisie onseker is. Hierdie problematiek is in die aard van die konsep "narrative point of view" self geleë. Streng gesproke bevat die term "point of view" twee betekeniskomponente. Eerstens, die tegniese perspektief ("angle of vision") van waaruit die skrywer-verteller die vertelde wêreld waarneem en vir die (implisiete/geïdealiseerde) leser aanbied. Tweedens, die ideologiese perspektief van waaruit die skrywer-verteller die vertelde wêreld evalueer, sodat hy dit waarneem soos hy dit waarneem en tegnies aanbied. Baie literêr-kritici (vgl. bv. Kenney 1966), eksponente van veral die skool van die vroeëre "New Criticism", vermy die tweede betekeniskomponent. Hulle konsentreer in hulle definisie van "point of view" alleen op die "verteltegnieke" sonder vermelding van die skrywer-verteller se "ideologiese perspektief" wat grondliggend aan die tegniek is. Volgens ander literêr-kritici (vgl. bv. Lanser 1981 en Fowler 1982) is hierdie verskynsel 'n ongelukkige tendens. Lanser en Fowler, byvoorbeeld, verwelkom daarom ' $n$ benadering soos dié van Boris Uspensky (1973) wat die skrywer-verteller se "ideologie" uit sy "tegniek(e)" wil aflees. Uspensky is sterk beïnvloed deur die literatuurteoretiese benadering wat bekendstaan as die "Russiese Formalisme". Hierdie benadering het die Amerikaanse "New Criticism" sodanig beïnvioed dat Polzin (1980: 100) 'n onderskeid tref tussen die sogenaamde "'old' New Criticism" en die "'new' New Criticism" (vgl. ook Hawkes 1977: 151-60).

Die studie van "narrative point of view" kan in verskeie rigtings opgaan. Dit is opvallend dat literêr-kritici wat hierdie benadering in die letterkunde toepas, hulle gewoonlik tot sekere aspekte van die ondersoek beperk. Hierdie verskynsel kan toegeskryf word aan e- 
nersyds die geweldige omvang van die benadering en andersyds aan die bovermelde ambivalente aard van die konsep "point of view".

Die ondersoek kan byvoorbeeld bestaan uit die vraag of die skrywer-verteller se perspektief eksplisiet of implisiet in sy teks manifesteer. Dit kan die vorm aanneem van 'n studie van bloot die interrelasies tussen die verskillende perspektiewe van waaruit die onderskeie karakters aangebied word of die ondersoek na watter karakter(s) die "draer(s)" is van die skrywer-verteller se perspektief. Die studie kan ook bestaan uit 'n ondersoek na die manifestasie van die skrywer-verteller se perspektief op verskillende vlakke in die vertelling, soos die vlak van karaktertekening of die vlak van tyd en ruimte (kyk bespreking hieronder). In die studie van karaktertekening is die vraag watter karakter(s) die "draer(s)" is van die skrywer-verteller se perspektief, uiteraard baie belangrik, sowel as die analise van die interrelasie tussen die verskillende perspektiewe van waaruit die onderskeie karakters vertel word. Laasgenoemde ondersoek staan in noue verband met die ontleding en beskrywing van die "plot" (kyk bespreking hieronder) van die vertelling.

Die werkwyse van Uspensky, waarby ons aansluit, ondersoek die "vertellersperspektief" (= "narrative point of view") soos dit op bovermelde "vlakke" in 'n vertelling manifesteer. Uspensky onderskei ten minste vier "vlakke" in 'n vertelling. Hy verwys daarna as die ideologiese, fraseologiese, psigologiese en tyds- en topografiese vlakke. In 'n simplekse vertelling manifesteer die vertellersperspektief eenduidig op al die vlakke. Wat' $n$ vertelling nog meer simpleks kan maak, soos in die geval van die evangelies, is die verskynsel dat die verteller se eenduidige perspektief deurgaans op al die vlakke ooreenkom en selfs identies is met die perspektief van waaruit een van die karakters (in die evangelies: die hoofkarakter) aangebied word.

\section{DIE VERTELLERSPERSPEKTIEF OP DIE IDEOLOGIESE VLAK}

\section{1}

Die ideologiese vlak in ' $n$ vertelling is grondliggend aan die ander vlakke. Uspensky (1973: 8) verduidelik hierdie verband van die ideologiese vlak met die ander vlakke in 'n vertelling aan die hand van die begrippe "oppervlaktestruktuur" en "dieptestruktuur" wat in die Strukturalisme ' $n$ belangrike rol speel. In die Strukturalisme word ' $n$ onderskeid getref tussen die niveau van waarneming (die oppervlaktestruktuur) en die niveau van grondliggende bedoelings (die dieptestruktuur). Die vertellersperspektief op die ideologiese vlak kan, in die lig van bogenoemde analogie met die Strukturalisme, 
bestempel word as die "idee" wat die grondliggende prinsiep uitmaak waarvolgens die vertelling en sy vertelelemente gekonstitueer is. Dit is hierdie "elemente" waarna deur middel van die uitdrukkinge fraseologie, psigologie, en tyd en ruimte verwys word. Dit kom met ander woorde daarop neer dat die verteller se ideologiese perspektief manifesteer op die fraseologiese, psigologiese, en tyd- en topografiese vlakke - die eventuele verskyningsgestaltes van die vertelling en sy vertelelemente op die oppervlak.

Die verband tussen die ideologiese vlak (die dieptestruktuur) en die ander vlakke in 'n vertelling (die oppervlaktestruktuur), asook die analogie tussen die "vertellersperspektief"-analise en die Franse Strukturalisme (soos beoefen deur onder andere A.J. Greimas), kan onderskeidelik met behulp van die volgende twee paradigmas verduidelik word:

Figuur (i): Die Franse Strukturalisme

\begin{tabular}{|c|c|}
\hline oppervlaktestruktuur & $\leftarrow$ Aktantiële relasies \\
\hline dieptestruktuur & $\leftarrow$ Semantiese universum \\
\hline
\end{tabular}

Figuur (ii): Die "vertellersperspektief" -analise
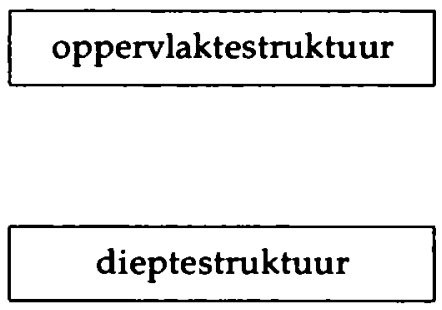

\author{
Fraseologie \\ $\leftarrow$ Psigologie \\ Tyd en topografie
}

$\leftarrow$ Ideologie

(Sisteem van idees)

Die analise van die fraseologiese, psigologiese, en tyds- en topografiese vlakke is die sleutel vir die eksegeet om die verteller se ideologiese perspektief(-we) van waaruit hy sy vertelling aanbied, te identifiseer. Wat die evangelies betref, kan die ideologiese perspektief(-we), in die algemeen gesien, beskou word as die evangelis se "teologiese idee(s)" van waaruit hy die evangelie oor Jesus Christus waarneem, evalueer en aanbied. 


\section{2}

Die belangrikste saak wat in die ondersoek na die vertellersperspektief op die ideologiese vlak uitgemaak moet word, is die vraag wie se perspektief deur die verteller ingeneem word in sy ideologiese evaluering en waarneming van die vertelde wêreld. Laat die skrywer die verteller 'n perspektief inneem wat ooreenkom met die skrywer s' $n$, of met dié van die normatiewe sisteem van die "vertelde wêreld", in onderskeid met die norme van die skrywer (en wat miskien in botsing daarmee staan)? Of neem die verteller die perspektief in van een (of meer) van die vertelde karakters?

\section{3}

Ons het reeds na die simplekse aard van die evangelies as verteltekste verwys. Die simpleksiteit van 'n evangelie as vertelteks manifesteer verder daarin dat die verteller se ideologiese perspektief met die perspektief van die skrywer saamval en met die perspektief van die protagonis ooreenkom. Dit bring mee dat alle gebeure, karakters en dies meer in die onderskeie evangelies konstant deur één spesifieke perspektief aangebied word, dit wil sê vanuit dié van één karakter, naamlik Jesus. Só ' $n$ tipe karakter in 'n vertelling word soms die "view-point"-karakter genoem. Die ideologiese perspektief van die verteller manifesteer in dit wat die "viewpoint"-karakter doen, praat, dink, ensovoorts en in die wyse waarop hy optree, praat ensovoorts. Hierdie één perspektief weerklink in elke episode in die vertelling, want die perspektiewe van waaruit die ander karakters vertel word, asook ander fraseologiese, psigologiese en tyds- en topografiese gegewenhede, is daaraan ondergeskik, daarby ineengeskakel en dien as die onderbou daarvan. Wat die evangelies betref, kom dit daarop neer dat die perspektiewe van die karakters (die Joodse leiers, die Joodse skare, die heidene, Johannes die Doper en die dissipels) geëvalueer moet word in terme van die perspektief van waaruit die protagonis, Jesus, vertel word. Die aard van hierdie dominante perspektief verskil van evangelie tot evangelie.

\section{4}

'n Komplekse vertelling vertoon 'n meervoudige evaluerende ideologiese vertellersperspektief. Daar kan met ander woorde in ' $n$ komplekse vertelling verskeie ideologiese perspektiewe bestaan wat saam 'n ingewikkelde netwerk van relasies kan toon. Uspensky (1973: 10) noem só ' $n$ vertelling ' $n$ "polyphonic narration". In só ' $n$ "manyvoiced" vertelling kan die verteller sy posisie opeenvolgens verskuif. Die verteller se perspektief kan byvoorbeeld op die onderskeie 
vlakke in 'n vertelling (fraseologies, psigologies en tyds- en topografies) varieer. Dit kan ook gebeur dat die verteller se perspektief in 'n komplekse vertelling in een episode saam kan val met dié van waaruit ' $n$ bepaalde karakter aangebied word en in die volgende episode met dié van waaruit 'n ander karakter vertel word. 'n Verwisseling van die verteller se perspektief kan selfs in dieselfde episode plaasvind. Verskeie variasies is uiteraard moontlik en vertellings kan derhalwe grade van simpleksiteit en kompleksiteit vertoon.

\section{DIE VERTELLERSPERSPEKTIEF OP DIE FRASEOLOGIESE VLAK}

\section{1}

Die studie van die vertellersperspektief op die fraseologiese vlak hou hom besig met wat Uspensky (1973: 19) die intensie van "speech characteristics" noem. Dit is die studie van daardie perspektief wat die verteller met behulp van diksie uitdruk. Diksie is die verteller se uitoefening van keuses met betrekking tot bepaalde seggingswyses waarop idees uitgedruk kan word. Hierdie ondersoek kan verskillende fasette vertoon. Ons verwys vervolgens alleen na enkele van dié fasette.

\section{2}

Die verskynsel in die evangelies dat die skrywer van 'n evangelie terselfdertyd die verteller daarvan is, getuig van die keuse van die evangeliste om hulle vertellinge vanuit 'n derdepersoons-vertellersgesigshoek aan te bied en nie vanuit dié van 'n eerstepersoon nie. In 'n eerstepersoons-vertelling is die verteller self ' $n$ karakter en hy praat van homself in die persoonlike voornaamwoord "Ek". In 'n derdepersoons-vertelling is die verteller iemand buite die teks en hy verwys na sy karakters deur middel van allerlei soort "name", soos byvoorbeeld eiename, persoonlike voornaamwoorde en titulêre benaminge ( $=$ titels).

\section{3}

'n Derdepersoons-verteller kan ook met behulp van ander soort verteltegnieke sy vertelling op ' $n$ bepaalde wyse aanbied, soos byvoorbeeld die sogenaamde omniscient point of view of die limited point of view. Die derdepersoons-verteller wat 'n "omniscient point of 
view" inneem, vertel onbeperk die optredes en gesindhede van die "hy"/"sy"/"hulle"-karakters sonder dat hy of enige getuies self by die vertelde gebeurlikhede teenwoordig was. Hy beskryf die karakters se emosies; hy weet van sommige dinge met betrekking tot die karakters, terwyl hulle dit self nie weet nie; hy wend karakter- en stemmingsbewegings soos ironie en sarkasme aan, soos hy wil; hy laat sy karakters vry beweeg ten opsigte van tyd en plek volgens sý ideologiese perspektief. Wanneer 'n derdepersoons-verteller 'n "limited point of view" inneem, beperk hy die "alwetendheid" en "alomteenwoordigheid" ten opsigte van wat ervaar, gedink of gevoel word, tot ' $n$ enkele karakter of hoogstens 'n baie klein groepie karakters in die vertelling. Beide vertellersperspektiewe, naamlik die "omniscient point of view" en die "limited point of view" kom in al die evangelies voor. Die evangelies is vanuit hulle totaliteit gesien, derdepersoons-"omniscient" vertellinge. Tog kom die verteller se perspektief ooreen met dié van waaruit Jesus in die onderskeie evangelies aangebied word. Aan die een kant laat die verteller sy karakters optree soos hy hulle wil laat optree, maar terselfdertyd beskryf en evalueer hy hulle optrede vanuit die perspektief van waaruit Jesus aangebied word.

\section{4}

Die derdepersoons-verteller skep met behulp van die "omniscient point of view" of the "limited point of view" onderskeidelik distansie of nabyheid tussen homself en die karakters, tussen die karakters onderling en ook tussen die leser en die karakters. 'n Bepaalde karakter(s) kan byvoorbeeld optree as "draer(s)" van die verteller se "ominiscient"-perspektief, net soos in die geval van die verteller se ideologiese perspektief. In die evangelies is die protagonis, Jesus, ' $n$ karakter wat 'n "omniscient"-perspektief het, net soos die verteller. Soms gebeur dit dat Jesus "ekstern" beskryf word vanuit die "omniscient"-perspektief van die verteller (vgl. o.a. Mk 2:3 vv en Mt 9:36). Ander kere vereenselwig die verteller hom só met die "omniscient"perspektief van Jesus dat dit nie moontlik is om tussen die perspektief van Jesus en dié van die verteller te onderskei nie (vgl. o.a. Mt 26:46). Hierdie verskynsel in die evangelies dat die derdepersoonsverteller se "omniscient"-perspektief dikwels ooreenkom met dié van Jesus, is nie net 'n rigtingwyser vir die implisiete leser dat Jesus die belangrikste "draer" ("vehicle") is van die verteller se ideologiese perspektief nie, maar dra ook by tot die strukturele en inhoudelike eenheid van die "plot" van die onderskeie evangelies. Omdat Jesus vooraf weet wat in Jerusalem op Hom wag, verbind, byvoorbeeld, die verskillende vooraf-lydensaankondiginge in die Sinoptiese Evangelies (Mk 8:31; 9:31; 10:32 vv en parallelle) episodes aanmekaar 
en word die sinvolle ontplooiing en eenheid van die "plot" daardeur gedien en word ook spanningsvolle verwagtinge daardeur geskep.

\section{5}

Deur te let op 'n verteller se fraseologiese keuses, kom veral sy karaktertekening aan die lig. ' $n$ Verteller se ideologiese perspektief manifesteer hoofsaaklik teen die agtergrond van die perspektief(-we) wat die karakter(s) deur middel van dialoog, monoloog, optrede en gesindheid verteenwoordig. Met ander woorde, die eksegeet neem die perspektief van die verteller waar, hoofsaaklik deur die analise van die verskillende perspektiewe van waaruit die onderskeie karakters vertel word. Die perspektief van die verteller word dus in fokus geplaas deur die wyse waarop die perspektiewe van die verskillende karakters in relasie met mekaar funksioneer. Breedweg gesien, kan karakters die volgende funksionele rolle vervul: dié van die protagonis, objek (adres), antagonis en helper.

\subsubsection{Protagonis}

Die protagonis (held) is een van die belangrike karakters, as nie dié belangrikste nie, in die "plot" van 'n vertelling. In sy optrede, redes en houding vind die "plot" sy ontwikkeling en momentum. In die evangelies funksioneer Jesus as die protagonis.

\subsubsection{Objek}

'n Karakter is 'n "draer van waardes" ("bearer of values") (vgl. Vandermoere 1976: 30). Wanneer hierdie "values" deur 'n ander karakter beliggaam word, dan is hy 'n "objek van verwesenliking" ("an object of desire"). Wanneer dit nie gebeur nie, 'n "object of aversion". In die Matteusevangelie is die "skare" die primêre "objek" (adres) van die Jesussending (vgl. Van Aarde 1982b: 87-94). Die aard van dié sending word by die aankondiging van die aanvang daarvan (Mt 1:21 vv) vermeld, naamlik die "vergifnis van die sonde van die laós". (Die terme ho labs en hoi ochloi funksioneer min of meer as sinonieme in die Matteusevangelie.) Soms is hulle respons "neutraal" (o.a. Mt 13:13) en dan weer "positief" (o.a. Mt 15:31; 21:9), maar ander kere "negatief" (o.a. Mt 13:53-8). Uiteindelik verwerp hulle saam met hulle leiers (pâs ho laós) Jesus (Mt 27:25). Wat die Markus- en Lukasevangelies betref, kan daar miskien 'n saak uitgemaak word (vgl. onderskeidelik Rhoads 1982 en Resseguie 1982) dat die dissipels die primêre "objek" van die onderskeie Jesussendings is. 


\subsubsection{Antagonis}

Die funksie van die antagonis in 'n vertelling bestaan gewoonlik uit die dwarsboming van die protagonis se sending. Hy probeer keer dat die protagonis se sending suksesvol afloop. Die Joodse leiers funksioneer in die evangelies as die antagonis. In sekere vertellings kan die antagonis se rol positief van aard wees deurdat hy die protagonis in die loop van die uitvoering van sy sending van mislukking of ondergang kan red (vgl. Vandermoere 1976: 30). Die verhouding tussen die protagonis en die antagonis in ' $n$ vertelling, of laasgenoemde se rol negatief of positief van aard is, skep altyd konflik en derhalwe, uit die oogpunt van die leser, spanning.

\subsubsection{Helper}

Die helper(s) in 'n vertelling is die karakter(s) wat ' $n$ ander karakter help om dié se "waardes" te verwesenlik (kyk weer afdeling 3.5.2). Vorster (1980: 128) toon aan dat die dissipels in die Markusevangelie as die veronderstelde helpers van Jesus in sy realisering van die koninkryk van God geroep word (Mk 1:16-20). Dit blyk egter dat hulle in der waarheid in 'n sekere sin, veral vanaf Mk 8:27-9:1 en volgende perikope, as die helpers funksioneer van die antagonis (die Joodse leiers) in dié se strewe om die handhawing van die godsdiens van die dag, naamlik die Judaïsme. In die Matteusevangelie word min of meer 'n soortgelyke tendens by die dissipels aangetref. Aan die een kant het hulle insig in hulle roeping as helpers van Jesus, maar aan die ander kant kom hulle met optredes vorendag wat dieselfde kenmerke as dié van die Joodse leiers toon (kyk Van Aarde 1982a).

\subsection{5}

Dit is moontlik dat daar in ' $n$ vertelling, benewens bogenoemde vier funksionele rolle, nog twee ander kan voorkom wat 'n karakter kan vervul, naamlik dié van donor ("gewer") en/of dié van arbiter. Eersgenoemde is ' $n$ funksionele rol wat Vladimir Propp in die sogenoemde "volksliteratuur" onderskei van dié van die helper. Dit het betrekking op daardie karakter in die sprokie wat vir die held (protagonis) spesifiek magiese towerkrag ("Zaubergaben") voorsien sodat hy sy doel kan bereik (vgl. o.a. Propp 1978: 76). Laasgenoemde rol, dié van arbiter, het betrekking op die oplos van 'n konflik tussen twee opponerende karakters deurdat 'n derde party die opponerendes laat ooreenkom of die wil van die derde party laat aanvaar (vgl. Vandermoere 1976: 30). Wat die evangelies betref, word die konflik tussen Jesus en die Joodse leiers nie opgelos nie. 'n Karakter in die rol van arbiter funksioneer derhalwe in hierdie verband nie. Maar wat die rol van "donor" betref, is dit 'n vraag of die Heilige 
Gees in sy optrede met betrekking tot Jesus, nie as sodanig in die vier evangelies en Handelinge funksioneer nie.

\subsection{6}

Sommige karakters in 'n vertelling vervul 'n "dekoratiewe rol" wat nie beslissend is vir die ontwikkeling van die "plot" nie. Inteendeel, die literêre funksie(s) van sulke karakters wissel dienooreenkomstig die ontwikkeling van die "plot". Rhoads (1982: 419) wys daarop dat die perspektiewe van waaruit karakters in die Markusevangelie aangebied word, soos Petrus se skoonmoeder en Josef van Arimatea, vir die geïmpliseerde leser norme verskaf hoe om die hoofkarakters te beoordeel. Volgens hom toon dié karakters in die Markusevangelie karaktertrekke soos kinderlike geloof, offerbereidheid en nederigheid. Soms funksioneer sulke karakters as pars pro toto in terme van ander hoofkarakters. In die Matteusevangelie kan die inwoners van Nasaret se optrede teen Jesus (Mt 13:53-8), byvoorbeeld, gesien word as ' $n$ vooruitflits van die latere optrede van die Joodse skare toe hulle Jesus by die kruis verwerp het (Mt 27:15-26). Ander kere verskaf 'n "minor" karakter alleen "kleur", oftewel agtergrond, aan 'n vertelling, soos byvoorbeeld die keiser in die perikoop oor die vraag met betrekking tot die betaal van belasting aan hom of nie ( $\mathrm{Mk}$ 12:13-17 en par.).

\section{6}

In 'n vertelling kom daar basies net twee soorte karakters voor, naamlik 'n simplekse karakter en 'n komplekse karakter. Eersgenoemde beliggaam deur die hele vertelling alleen ' $n$ eenduidige perspektief en laasgenoemde nie. By die "komplekse karakter" is die verrassingselement gewoonlik aanwesig. Só 'n karakter tree dikwels anders as die lesersverwagting op. Hy openbaar dikwels in optrede en gesindheid ' $n$ mate van huiwering, innerlike twyfel en tweespalt. Die teenwoordigheid van ' $n$ "komplekse karakter" in 'n vertelling help konflik aan en skep, uit die oogpunt van die leser, spanning. In die evangelies, is Jesus 'n "simplekse karakter", terwyl byvoorbeeld die dissipels die rol van 'n "komplekse karakter" vervul. Hierdie karaktertrekke word in die Matteusevangelie op 'n besondere wyse geteken. Jesus is die beliggaming van die optrede en gesindheid wat gekenmerk word deur die absolute gehoorsaamheid aan die wil van die Vader in die hemel. Hierdie selfde optrede en gesindheid word van die dissipels verwag. Aan die een kant het die dissipels in die Matteusevangelie, anders as by Markus, volledige "insig" in die aard van Jesus se persoon en werk. Hulle verstaan klaarblyklik ook die aard van hulle eie funksie as Jesus se "helpers". Aan die ander kant 
openbaar die dissipels in die Matteusevangelie, ten spyte van hulle volledige "insig", 'n "kleingeloof"-geneigdheid. Hierdie geneigdheid veroorsaak dat hulle dikwels met 'n perspektief vorendag kom wat ooreenkoms toon met dié van die opponente van Jesus, die Joodse leiers. Om hierdie skadukant van die dissipels uit te beeld, gebruik Matteus onder andere dieselfde benaminge vir die dissipels as wat hy elders in sy vertelling vir die Joodse leiers aangewend het (vgl. bv. Mt 7:5; 24:51 en 7:15, 22).

\section{7}

Benaming is een van die effektiefste literêre middele wat ' $n$ verteller kan aanwend om die perspektiewe van die verskillende karakters in hulle binêre relasies uit te druk. En hier dink ons veral aan benaminge wat as "titels" (Duits: "Würdeprädikationen") gebruik word. 'n Verteller kan byvoorbeeld by wyse van die aanwending van verskillende titulêre benaminge vir een karakter wys op die perspektiewe van die ander karakters wat elkeen afsonderlik (of sommige tesame) deur middel van sy eie tipiese benaming vir die betrokke karakter, sy perspektief ten opsigte van dié karakter (en die ander karakters) uitdruk. Dit is byvoorbeeld opvallend at terwyl die "groeps-benaming" mathētaí met die benaming didáskalos korreleer (vgl. Mt 10:24), didáskalos of rabbí nie in die mond van die dissipels met verwysing na Jesus in die Matteusevangelie funksioneer nie. Die relasie tussen 'n dissipel en Jesus word in dié evangelie deur die benaming kúrios uitgedruk (vgl. Van Aarde 1982b: 66-73). Die funksie van die benaming didáskalos vir Jesus in die mond van die Joodse leiers is om die aard van die opposisie wat daar tussen dié twee partye bestaan, te onderstreep, naamlik dat dit oor die interpretasie van die Tora as die wil van God gaan. In die gevalle waar die term kúrios in die Matteusevangelie funksioneer, word die perspektief van Jesus se gesag waarmee Hy optree, beklemtoon. Hierdie gesag het betrekking op Jesus se "radikale" interpretasie van die Tora in onderskeid met die interpretasie daarvan deur die Joodse leiers. Die dissipels, sowel as die potensiële navolgers van Jesus, moet egter ook hoor dat nie elkeen wat kúrie kúrie vir Hom sê, in die koninkryk van die hemel sal ingaan nie (vgl. Mt 7:21; 25:11), maar alleen dié wat die wil van die Vader, soos Jesus dit leer, doen.

\section{8}

In die konstituering van die evangelies as vertellinge het die evangeliste as redaktor-vertellers (kyk weer afdeling 1.2) gebruik gemaak van oorgelewerde tradisies. 'n Ondersoek na die aanwending van tradisies deur die evangeliste kan onses insiens beskou word as 'n 
faset van die studie van die vertellersperspektief op die fraseologiese vlak.

\subsection{1}

Tradisie en redaksie word nie in die vertellersperspektief-analise, soos wel in die tradisionele "Redaktionsgeschichte", geskei nie. Die "Redaktionsgeschichte" plaas die klem op die redaktor en sy bronne. Wat die vertellersperspektief-analise betref, word die tegnieke van die vertelkuns raakgesien en is daar 'n oog vir die feit dat die verteller met behulp van sy eie kontekstualisering van tradisies bepaalde perspektiewe geskep het. Tradisie èn redaksie word gesien as die materiaal waarmee die evangelis as verteller sy ideologiese perspektief op die fraseologiese vlak laat manifesteer. Die studie van 'n verteller se redaksionele verteltegniek is dus geïnteresseerd in die ideologiese motief wat geleë is agter die herrangskikking, modifisering, eliminering, uitbreiding, verkorting, ensovoorts van tradisies in die vertelling (kyk Van Aarde 1982a).

\section{DIE VERTELLERSPERSPEKTIEF OP DIE PSIGOLOGIESE VLAK}

\subsection{Inleiding}

Dié bepaalde deel van die ondersoek is veral gerig op "verba sentiendi" wat na menslike gevoelens en gedrag verwys. "Verba sentiendi" is uitdrukkinge soos "hy het gedink dat ...", "hy voel dat ...", "dit lyk vir hom dat ...", "hy weet dat ...", "hy erken dat ...", "hy herken ...", ensovoorts (vgl. o.a. Uspensky 1973: 85 en Fowler 1982: 228). Die studie van die vertellersperspektief op die psigologiese vlak hou verband met veral twee aspekte wat ons reeds in ons uiteensetting van die vertellersperspektief op die fraseologiese vlak bespreek het. Die een is die kwessie van die "omniscient" of die "limited point of view" (kyk afdeling 3.3). Die ander een is karaktertekening as sodanig (kyk afdelings 3.5 en 3.6). Enersyds word die tegniese wyse ("angle of vision" - kyk afdeling 1.4) bestudeer waarop 'n verteller toegang het (op 'n "omniscient" - oftewel "eksterne" - wyse of op 'n "limited" - oftewel "interne" - wyse) tot die karakters se bewussyn, denke, emosies, sensoriese waarnemings, gevoelens, ensovoorts. Andersyds word die psigologiese perspektiewe van waaruit karakters aangebied is, geïdentifiseer.

\section{2 "Eksterne" of "interne" vertellersperspektief}

Menslike gedrag word normaalweg op twee onderskeie wyses deur 
vertellers in literêre werke aangebied: 1 . Die verteller funksioneer as 'n buitestaander-waarnemer (duidelik gedefinieer of ongespesifiseerd) wat "ekstern" bloot die gedrag van die karakters vertel. Só 'n gesigshoek is die "omniscient point of view" waarna ons vroeër verwys het (afdeling 3.3). 2. Die verteller, ook vanuit 'n "omniscient"-gesigshoek, het toegang tot die karakters se psigologiese perspektiewe. Só 'n verteller is 'n "interne" waarnemer. Hierdie gesigshoek hou verband met die reeds vermelde "limited point of view" (afdeling 3.3).

Die "eksterne" verteller is gewoonlik ruimtelik en temporeel onbepaald en sy vertelling is in ' $n$ sekere sin "onpersoonlik". Fraseologies word sy waarneming uitgedruk met behulp van frases soos "hy (die karakter) het gesê ..." en "hy het aangekondig ...". Hierteenoor word die "interne" verteller se waarneming uitgedruk met behulp van "verba sentiendi" soos "hy dink", "hy voel", "hy was skaam", ensovoorts. Laasgenoemde frases is uitdrukking daarvan dat die verteller toegang het tot die bewussyn van die karakters, denke, emosies, sensoriese waarneming en gevoelens.

Die feit waarop ons vroeër gewys het, naamlik dat die "omniscient" en "limited points of view" mekaar in 'n vertelling kan afwissel en selfs gekombineerd kan voorkom, geld uiteraard ook van die "eksterne" en "interne" vertellersperspektiewe. Laasgenoemde is dan veral die manifestasie van die vertellersperspektief op die psigologiese vlak.

Petersen (1978b: 116 v) wys daarop dat die Markusevangelie gekenmerk word deur wat Uspensky (1973: 95 vv) noem "the simultaneous use of different positions". As verteller is Markus dikwels binne dieselfde episode 'n "eksterne" sowel as 'n "interne" waarnemer. Die wondervertelling van die genesing van die verlamde man (Mk 2:1-12) is hiervan ' $n$ voorbeeld. (Hierdie vertelling is ook illustrasie van die feit wat hierbo vermeld is, naamlik dat die vertellersperspektief op die psigologiese vlak uitgedruk word op die fraseologiese vlak.) Aan die een kant beskryf Markus in die derdepersoon dat die karakters in dié wondervertelling so-en-so meen of voel. Aan die ander kant vertel hy wat hulle menings of gevoelens is: "die skrifgeleerdes het hulleself in hulle harte afgevra" (vs 6); "Jesus het dadelik in sy gees geweet dat hulle by hulleself so redeneer" (vs 8); "almal was verbaas" (vs 12).

\subsection{Die psigologiese perspektiewe van karakters}

Psigologiese waarneming van die karakters deur die verteller is ' $n$ subgroep van wat bekend staan as "vertellerskommentaar" - 'n aspek wat veral in die studie van die vertellersperspektief op die tyds-vlak belangrik is (kyk afdeling 5.2.2). Sulke "kommentaar" dien 
vir die implisiete leser as ' $n$ effektiewe evaluasie-riglyn hoe om die vertelling vanuit die verteller se ideologiese perspektief te lees.

Wat die evangelies betref, bied sodanige "kommentaar" norme om die ideologiese perspektief van Jesus te onderskei van dié van die ander karakters. Sodoende word die verteller se ideologiese perspektief, wat met dié van Jesus ooreenkom, geïdentifiseer.

Resseguie (1982: 43) wys op voorbeelde in die Lukasevangelie waar die verteller die leser inlig dat Jesus bewus is van die gevoel van sy teëstanders dat hulle hom wil versoek (Lk 11:17); dat 'n Fariseër verwonderd was toe hy sien dat Jesus nie die gebruik nagekom het om voor die ete eers hande te was nie (Lk 11:38); dat Jesus sy teëstanders laat skaam kry het (Lk 13:17); dat die Fariseërs Jesus fyn dopgehou het (ēsan paratēroúmenoi) toe Hy by 'n vooraanstaande Fariseër gaan eet het (Lk 14:1); dat die Fariseërs beswaar gemaak het (diegógguzon) dat Hy saam met tollenaars en sondaars eet (Lk 15:1 vv), ensovoorts. Hierdie psigologiese waarnemings ("vertellerskommentaar") oor die motiewe en gevoelens van die Joodse leiers - hulle verontwaardiging, skaamte en verwondering dien om die skerp onderskeid tussen die ideologiese perspektief van die Joodse leiers en dié van Jesus te beklemtoon en om assosiasie identifikasie, simpatie of antipatie - by die implisiete leser met betrekking tot die vertelde karakters te suggereer.

\section{DIE VERTELLERSPERSPEKTIEF OP DIE TYDS- EN TOPOGRAFIESE VLAK}

\subsection{Inleiding: Die konsep "plot"}

Die studie van die konsepte "tyd" en "ruimte" in vertelmateriaal kan in verskeie rigtings opgaan. Die aspek wat ons hier in die fokus wil plaas, is onlosmaaklik gebind aan die konsep plot.

Die "plot" van 'n vertelling is die struktuur van gebeure of episodes van gebeure. Die "plot" is egter nie bloot 'n optelsom van die liniêre verloop van die gebeure of episodes van gebeure in 'n vertelling nie. Dit is eers wanneer ons sê hoe hierdie elemente in 'n vertelling in verhouding met daardie en ander elemente in dieselfde vertelling staan en hoe hulle saam georganiseerd funksioneer ter wille van ' $n$ bepaalde kommunikatiewe effek, dat 'n optelsom gelyk is aan die "plot" van die vertelling (vgl. Abrams 1971: 128). Volgens Aristoteles se literatuurteorie (vgl. Butcher 1951: 82) bestaan 'n goed gestruktureerde "plot" uit die liniêre sekwensie begin wat lei na 'n middelstuk en slot. Die begin van die "plot" lei die aksie in en skep verwagtinge; in die middelstuk word die handeling van die begin ontwikkel en dit veronderstel 'n ontknoping (denouement) wat in die slot uitgewerk word. Só gesien, is die gebeure of episodes van 
gebeure in ' $n$ vertelling kronologies èn kousaal met mekaar verbind wat' $n$ liniêr-sekwensiële opeenvolging van gebeure (die sekwensie "begin", "middelstuk" en "slot") meebring. Die Russiese Formalisme verwys hierna as "fabel", die materiaal waaruit ' $n$ vertelling bestaan. Petersen (1978 a: 47 vv) noem dit "story-time". Hy onderskei dit van "plotted time". Laasgenoemde word deur die Russiese Formalisme "sujet" genoem.

\section{2 "Story-time"}

\subsubsection{Die liniêre sekwensie: begin, middelstuk en slot}

Die studie van "story-time" bestaan primêr uit 'n ondersoek na die kronologiese kousaliteit tussen begin, middelstuk en slot in 'n vertelling - dit is as daar in hierdie verband vanuit die Aristoteliaanse paradigma na die "plot" van die vertelling gekyk sou word.

Volgens Vorster (1980: 30) word die begin van die Markusevangelie (Mk 1:1-15) gekenmerk deur die aankondiging van die Seun van God wie se doel dit is om die nuwe moontlikheid van die koninkryk van God in die lewe van die mense daar te stel. In die begin vind ons egter reeds ' $n$ gesuggereerde konflik en spanning in die berig oor Jesus se oorwinning oor Satan tydens die versoeking in die woestyn en in die berig oor die arrestasie van Johannes die Doper. In die middelstuk (Mk 1:16-14:42) word daar voortgebou met hierdie gegewens. Tot by Mk 8:27 word daar in 'n stygende lyn aangetoon dat Jesus, die Seun van God, sukses in sy doelstelling bereik deur die roep van volgelinge, deur te onderrig, mense gesond te maak en as oorwinnaar uit die strydgesprekke met Fariseërs te tree. In Mk 8:27-33 kom daar' $n$ wending in die suksesverhaal. Petrus bely Jesus as die Christus, maar hy kan nie begryp dat Jesus as die Christus moet ly nie. Met behulp van drie lydensaankondiginge (Mk 8:31; 9:31 en 10:32 vv) word daar vooruit gegryp na wat in die res van die evangelie gaan gebeur. Jesus leer die dissipels wat navolging in lyding beteken, maar die dissipels se onvermoë om te verstaan, kom al hoe meer na vore. Dit word ook al hoe meer duidelik dat die plan van die Joodse leiers om Jesus dood te maak, gaan slaag. Dit is 'n plan wat op drie plekke deur die evangelis ontbloot word (Mk 3:6, 12:12 en 14:1). Hierdie opposisie word na die slot van die evangelie (Mk 14:43-16:8) deurgetrek en bereik sy hoogtepunt by die uiteindelike uitroep van Jesus aan die kruis waar Joodse leiers, Romeinse owerhede en selfs dissipels en die volk sy teenstanders word. Maar Jesus slaag tog in sy doelstelling in die tweede deel van die "slot", naamlik in die berig oor die opstanding. Die doel word bereik: Jesus oorwin die dood en staan op.

Wat die Matteusevangelie betref, onderverdeel die evangelie as 
geheel, volgens Combrink (1982:11-25), in Mt 1:1-4:17 (begin), Mt 4:18-25:46 (middelstuk) en Mt 26:1-28:20 (slot). Jesus word in die begin as die protagonis geïdentifiseer, die Joodse leiers, soos verteenwoordig deur koning Herodes die Grote en die owerpriesters en skrifgeleerdes, as die antagonis en die dissipels as die helpers. Die konflik en spanning wat tydens die openbare optrede van Jesus vanaf Mt 4:18-25:46 op die voorgrond tree, begin met ander woorde reeds in Mt 1:1-4:17. Die middelstuk bestaan volgens Combrink uit drie dele: 1. Jesus se dienswerk met betrekking tot Israel in woord en daad en die gesagverlening aan die dissipels om hierdie dienswerk te kontinueer (Mt 4:18-11:1). 2. Jesus word verwerp èn bely (Mt 11:2-16:20). 3. Jesus op weg na sy dood en opstanding (Mt 16:21-25:46). In die slot bereik die opposisie teen Jesus sy doel, maar wat belangrik is, is dat Jesus selfs hier die gesag en die inisiatief behou. Die dissipels se sendingopdrag van Mt 4:19 word hernu, terwyl die rol van die Joodse skare beslissend verander vanaf potensiële navolgers na mense wat, soos hulle leiers van die begin af, Jesus verwerp en wil doodmaak.

Hoewel daar ten opsigte van sekere detail van bogenoemde indelings van die Markus- en Matteusevangelies onderskeidelik deur Vorster en Combrink, verskil van opinie kan wees, is dit goeie weergawes van dié twee evangelies se "story-time". Wat die Lukasen Johannesevangelies betref, kyk onderskeidelik Petersen (1978a:81-92) en Du Rand (1982:19-25).

\subsection{2 "Vertelde tyd" en "bespreekte tyd"}

Die studie van "story-time" kan ook bestaan uit 'n ondersoek na die verskillende maniere waarop ' $n$ verteller van die liniêre tydsverloop "afgewyk" het. Voorbeelde van sulke "afwyking" is prospeksie, retrospeksie en kommentariëring. ' $n$ Ondersoek hierna hou hom besig met wat bekend staan as "besprochene Welt" ("bespreekte tyd")teenoor die "liniêre verloop" as "erzählte Welt" ("vertelde tyd"). Simplisties gestel, kan "vertelde tyd" van "bespreekte tyd" daarin onderskei word dat eersgenoemde vertelmateriaal is waarin die verteller blote inligting wil verskaf en laasgenoemde vertelmateriaal waarin hy wil evalueer. Omdat aspekte van die verteller se ideologiese perspektief veral in die "bespreekte tyd" manifesteer, dien die "bespreekte tyd" vir die leser as belangrike rigtingwyser waarvolgens die vertelling gelees moet word.

Sowel "vertelde tyd" as "bespreekte tyd" kan die vorm aanneem van aforistiese frases of dit kan die vorm aanneem van uitgebreide diskoerse. Die "vertellerskommentaar" wat ons in afdeling 4.3 bespreek het en wat ons daar "psigologiese waarneming" genoem het, is voorbeelde van kort fraseologiese segginge. Wat uitgebreide diskoerse betref, wys Vorster (1982:15) daarop dat die parabel-diskoers 
van Mk 4:1-34, direkte rede van Jesus, as "bespreekte tyd" in die Markusevangelie funksioneer. In dié verband is een van die opvallende kenmerke van die Matteusevangelie die afwisseling van uitgebreide "vertelde diskoerse" (Mt 1:1-4:22; 8:1-9:35; 11:2-12:50; 13:53-17:27; 19:2-22:46 en 26:1-28:20) met "bespreekte diskoerse" (Mt 4:23-7:29; 9:36-11:1; 13:1-52; 18:1-19:1 en 23:1-25:46) (Kyk verder Van Aarde 1982b: 123-8.)

\section{3 "Plotted time"}

Met "plotted time" word bedoel wat Wellek en Warren noem: "plot as mediated through 'point of view'" (kyk Petersen 1978 a: $47 \mathrm{v}$ ). "Plotted time" veronderstel ten minste een "handelingslyn" wat oor 'n "begin", "middelstuk" en "slot" loop. Hierdie handelingslyn (ook genoem: "sekwensie") bestaan uit die suksesvolle afloop van 'n protagonis se sending na 'n objek (kyk weer afdeling 3.5). Daar kan egter ook 'n tweede (en meer) handelingslyn(e) in 'n vertelling voorkom wat dan 'n "newe-sekwensie(s)" vorm (vgl. Lämmert 1972: 112-39). Só 'n afsonderlike selfstandige handelingslyn beskik oor sy eie "storie" met sy eie "story-time", wat volledig met die primêre handelingslyn saam kan val of nie. Hoewel 'n "newe-sekwensie" van die "primêre sekwensie" moet verskil ten opsigte van ten minste ò "tyd" ò "ruimte" òf "karakters", bestaan daar uiteraard 'n bepaalde betekenisverband tussen die "primêre sekwensie" en die "newe-sekwensie". Hierdie betekenisverband kan byvoorbeeld korrelatief, oftewel analogies, van aard wees deurdat die een òf volledig parallel met die ander verloop ò op 'n simbolies-allegoriese wyse in die ander herhaal word (vgl. Lämmert 1972: 52-6). Dié twee handelingslyne kan ook voortdurend met mekaar in 'n vertelling afgewissel word.

In 'n vertelling waar meer as een handelingslyn voorkom, het die verteller kennelik sy vertelling volgens ' $n$ dieperliggende prinsiep as bloot die streng kronologiese of kousale, georganiseer. Die ondersoek na en identifisering van hierdie prinsiep is die studie van die verteller se ideologiese perspektief op die tyds- en topografiese vlak.

Toegepas op die gelykenis van die huweliksmaaltyd in Mt 22:1-14, funksionerende as ' $n$ outonome mikrovertelling, bring ' $n$ studie van "plotted time" die volgende aan die lig:

Vier handelingslyne kan geïdentifiseer word. Twee hiervan is voltooide handelingslyne, omdat dit 'n suksesvolle/onsuksesvolle sending van 'n protagonis na 'n objek ("of desire/aversion") (kyk afdeling 3.5.2) verhaal. Die een is die sending van slawe (protagonis) deur' $n$ koning na genooide gaste in die stad (objek) wat die uitnodiging na die huweliksmaaltyd van die koning se seun weier en gestraf word (vss 4-7). Die ander een is die sending van die slawe 
(protagonis) na ongenooides buite die stad (objek) wat die uitnodiging aanvaar en tog word een van hulle gestraf (vss 8-14).

Die liniêre sekwensiële opeenvolging van episodes ("story-time") in die twee voltooide handelingslyne sien soos volg daaruit: 1 . Die koning stuur sy slawe met 'n uitnodiging aan die genooides in die stad ('n "partikularistiese" sending) dat die huweliksmaaltyd van sy seun gereed is (begin); hulle weier die uitnodiging en party beledig selfs die slawe en maak hulle dood (middelstuk); die sending word nie suksesvol afgehandel nie, maar die koning straf die moordenaars deur sy soldate opdrag te gee om hulle dood te maak en hulle stad af te brand, omdat hulle die huweliksmaaltyd onwaardig is (slot). 2. Die koning stuur sy slawe met' $n$ uitnodiging aan die ongenooides buite die stad ('n "universele" sending) dat die huweliksmaaltyd gereed is (begin); hulle aanvaar die uitnodiging en die maaltyd realiseer (middelstuk); die koning doen inspeksie en vind dat ' $n$ gas nie by die huweliksmaaltyd van sy seun tuishoort nie; die bediendes van die koning kry opdrag om hom onherroeplik in die "diepste duisternis" buitekant die huweliksfees uit te gooi (slot).

Dit is duidelik dat daar ' $n$ opvallende analogie tussen bogenoemde twee handelingslyne bestaan. Die verteller se ideologiese perspektief kom aan die lig wanneer die aard van dié analogie (dit wil sê, die betekenisverband tussen die onderskeie handelingslyne) omskryf kan word. Die beskrywing van die "plot" in terme van hierdie "betekenisverband", is dit wat bedoel word met die uitdrukking: "plot as mediated through 'point of view'". Só gesien, is dit opvallend dat een van die "ongenooides", hoewel hy in teenstelling met die "genooides" die uitnodiging na die huweliksmaaltyd aanvaar het, 'n soortgelyke straf ondergaan as die "genooides". Die afleiding wat hieruit gemaak kan word, is dat die afwesigheid van die "bruilofsklere" wat hom vir die huweliksmaaltyd ongeskik gemaak het, (vss $11 \mathrm{v}$ ) ' $n$ bepaalde verwysing het. En dit is dat sy gesindheid/optrede, ten spyte van sy aanvaarding van die uitnodiging, ooreenkoms toon met dié van die antagonis in die eerste handelingslyn. Ons het dus te doen met ' $n$ korrelatief-analogiese betekenisverband tussen die twee handelingslyne. Ons kan aanvaar, soos die meeste Matteuskenners ook meen, dat die karakters en hulle handelinge in dié gelykenis allegories betrekking het enersyds op die optrede/gesindheid van die Joodse leiers (die eerste handelingslyn) en andersyds op dié van die implisiete leser, die lidmate van Matteus se gemeente (die tweede handelingslyn). Hierdie implisiete leser word deur Matteus met die "historiese" dissipels geassosieer. Die beeld van die implisiete leser wat in die gelykenis van die huweliksmaaltyd na vore kom, toon dieselfde kompleksiteit as wat ons in afdeling 3.6 met betrekking tot Matteus se dissipelbeeld uitgewys het. 


\subsection{Ruimte}

\subsection{1}

Ruimtelike ordening in vertelmateriaal is aan die sekwensiële tydsverloop in 'n vertelling gebonde. 'n Skilderstuk kan van links na regs en van regs na links waargeneem en geëvalueer word sonder dat die topografie sy fokus verloor. 'n Vertelling kan nie só waargeneem word nie. Anders as die skilderkuns, word vertelmateriaal eers met betrekking tot sy liniêre sekwensie waargeneem en dan met betrekking tot sy topografie in onlosmaaklike verband met eersgenoemde (vgl. Uspensky 1973: $76 \mathrm{vv}$ ).

\subsection{2}

Met die term "ruimte" word bedoel alles in 'n vertelling wat 'n tipe "ruimtelikheid" besit (vgl. Vandermoere 1976: 12v). Dit sluit die plek in waarbinne karakters hulle bevind. In die bovermelde gelykenis van die huweliksmaaltyd is byvoorbeeld die "stad" (Mt 22:7) sowel as die "deurweë" (Mt 22:9) belangrike plekaanduidinge. "Ruimtelikheid" sluit ook aspekte in soos die plekke se toebehore, die wyse waarop 'n plek voorgestel word, asook die eksplisiete of implisiete gevoelswaarde (atmosfeer) wat aan plekke geheg word. Die vermelding van die "bruilofsklere" (Mt 22:12), byvoorbeeld, is deel van die toebehore van die "huweliksmaaltyd" wat 'n plekaanduiding is. Die uitdrukkinge "diepste duisternis", asook "huil" en "tandekners" (Mt 22:13), byvoorbeeld, druk die wyse uit waarop die plek buite die huweliksmaaltyd voorgestel word, sowel as die negatiewe gevoelswaarde wat met hierdie plek geassosieer word.

\subsection{3}

Die geslaagdheid van ' $n$ vertelling staan nie in direkte verband met die feit al dan nie dat die "ruimtelikheid" daarin dié is van die "werklike wêreld" nie (kyk afdeling 1.3). "Ruimte" in 'n vertelling is "fiktiewe ruimte". Dit is 'n literêre kategorie wat binne die "vertelde wêreld" funksioneer - die ruimte waarbinne die vertelde karakters, die verteller en die implisiete leser beweeg. Die "geloofwaardigheid" van byvoorbeeld die evangelies word nie bepaal deur die vasstelling van die historiese feitelikheid daarvan dat Jesus net een keer vanaf Galilea na Jerusalem gereis het (die Sinoptiese Evangelies) of meer kere (die Johannesevangelie) nie. Tog is dit belangrik, uit 'n kommunikatiewe oogpunt gesien, dat geografiese verwysings in vertelmateriaal wat nie die produk van "fiksie" (in die sin van "verbeelding") is nie, soos die evangelies, nie "lewensvreemd" vir die implisiete leser moet voorkom nie. Hoewel die evangeliste "fiktiewe ruimte" (ruimtelikheid wat binnetekstueel refereer) skep, 
staan hierdie ruimte in analogie met die "reële ruimte", anders sal die "vertelde wêreld" vir die implisiete leser onverstaanbaar en onaanvaarbaar wees.

\subsection{4}

Daar kan in die funksionering van ruimte onderskei word tussen ruimte as speelruimte en ruimte as belangeruimte. Indien 'n verteller'n verband lê tussen karakterisering en ruimtebeelding, funksioneer ruimte nie meer as blote lokaalaanduiding ("speelruimte") nie, maar as "belangeruimte" (vgl. Blok 1960: 189-211). "Belangeruimte" vertoon altyd gestruktureerdheid. Die struktuur van "belangeruimte" hou verband met die aard van die funksionele rol wat dit met betrekking tot karakterisering vervul. Dit kan byvoorbeeld milieu- en atmosfeerskildering wees. Dit kan ook simboliese waarde besit. So verwys byvoorbeeld die "huweliksmaaltyd" van die koning se seun in Mt 22:1-14 na die "Messiasryk", die "stad" as die plek van die genooides na Jerusalem, die simbool van die Jodedom en alles wat dit inhou; die "deurweë" waar almal sonder uitsondering, goed of sleg, genader word, na die universele sending, ensovoorts. Ruimte kan selfs die rol vervul van 'n funksionele karakter self, byvoorbeeld dié van 'n "helper" of selfs dié van 'n protagonis of antagonis (kyk weer afdeling 3.5). 'n Vertelling kan byvoorbeeld handel oor die mens se stryd teen die elemente van die natuur. In die gelykenis van die saaier (Mk 4:1-20 en par.) funksioneer die plek waar die saad geval het en toe deur die voëls opgepik is, inderdaad as die antagonis, die Satan (kyk vs 15). Dit is dus duidelik dat "belangeruimte" die ideologiese perspektief(-we) van die verteller en dié van waaruit die karakters vertel word, openbaar. Die strukturering van ruimte in die gelykenis van die huweliksmaaltyd is onmiskenbaar gedoen vanuit twee opponerende ideologiese perspektiewe, naamlik dié van die Joodse leiers (= die "genooides in die stad") en dié van Jesus (= die "seun van die koning"). Die deelkry aan die "koninkryk van die hemel" (vs 2) word in dié mikrovertelling beskryf in terme van die opposisie enersyds tussen diegene binne die stad en diegene buite die stad en andersyds tussen die deelhê aan die huweliksmaaltyd en die afbranding van die stad of die uitgooi in die "diepste duisternis".

\subsection{5}

Ruimte se gestruktureerdheid geskied in 'n vertelling altyd vanuit 'n bepaalde tegniese vertellersperspektief (vgl. Vandermoere 1976: 38 vv), naamlik òf vanuit die gesigshoek van die skrywer-verteller òf vanuit dié van een van die vertelde karakters. (Hierdie alternatief moet met die reeds vermelde onderskeid tussen die sogenoemde "omniscient point of view" en die "limited point of view" in ver- 
band gebring word.) Afgesien van watter een van dié twee aanbiedingswyses respektiewelik (of gekombineerd) ook al in 'n vertelling voorkom, word ruimte, breedweg gesien, op twee wyses aangebied. Die beskrywing daarvan (vanuit die gesigshoek van òf die skrywerverteller òf een van die vertelde karakters) kan aan die een kant só gedetailleerd wees dat die leser op die hoogte is met betrekking tot besonderhede. Vandermoere (1976: 39) noem dit "beskrywing 'en bloc'". Aan die ander kant kan alleen dit wat direk met betrekking tot ' $n$ bepaalde handeling relevant is, beskryf word. In só 'n geval sal die leser nie ' $n$ akkurate insig in die besonderhede van die vertelde ruimte verkry nie. Biografiese vertellinge vertoon, wat ruimtebeelding betref, kenmerke van beskrywinge "en bloc". Die evangelies besit kennelik nie dié soort vertelkarakter nie. Hulle is vertellinge waarin ruimte vanuit die verteller se bepaalde ideologiese perspektief aangebied is.

\section{DIE WAARDE VAN DIE VERTELLERSPERSPEKTIEF- ANALISE}

Die analise van die verteltegnieke in ' $n$ vertelling en die identifisering van die ideologiese perspektief grondliggend aan dié tegnieke, is 'n poging om uit die doodloopstraat te kom waarin die interpretasie van die evangelies beland het. Dié dilemma is grotendeels toe te skryf aan enersyds die historisme en die positivisme waaraan die tradisionele historiese kritiek hom skuldig maak en andersyds die fenomenologisme van die strukturale benaderingswyse. Narratologie is nie ' $n$ diakroniese benadering nie, maar ook nie ' $n$ akroniese nie. Dit is ' $n$ sinkroniese studie wat aan die een kant nie vyandig staan teen die historiese ondersoek nie en aan die ander kant uitstekend inpas by ' $n$ hermeneutiese kommunikasiemodel wat rekening hou met die kommunikasiegebeure "sender-boodskap-ontvanger".

Gene Tucker het die basiese beginsel, wat onses insiens by enige metode van uitleg moet geld, soos volg saamgevat: "The fundamental rule of biblical exegesis is that the interpreter must be obedient to the text itself; that is, he or she must allow the texts to determine their interpretation" (Tucker 1975: v). Die wyse waarop Tucker hierdie beginsel toegepas wil sien, is egter, wat verteltekste betref, aanvegbaar. Hy het die tradisionele historiese kritiek in die oog gehad. Die vorm waarin skrywers van verteltekste, soos die evangelies, kommunikeer, bestaan uit 'n "plot", gekonstitueer deur karakters wat in ' $n$ bepaalde struktuur van tyd en ruimte beweeg. Die vertellersperspektief-analise is baie bruikbaar vir die ondersoek na dié verhaalstruktuur. Die rede hiervoor is geleë in die feit dat dit die meeste reg laat geskied aan die funksies wat die konstituerende prinsiepes van 'n vertelling vervul. Petersen (1980: $36 \mathrm{vv}$ ) formuleer 
dit soos volg: "The starting point of literary criticism ... is 'to accept the form of the work' .... our Gospels ... have a narrative form ... and an imaginative world into which one can enter. How? By participating in the form of the work .... A literary reading of a narrative text ... begins at the moment when we allow ourselves to be addressed by its textually immanent narrator. That is the first step. All others follow from it ... the narrator lures the reader into ... times and places by perspectively locating himself and the reader in the midst of the scenes and events he describes, enabling the reader to see, hear, and know things he would not have access to without the narrator's guiding voice. Through this device which literary critics call narrative point of view, the reader becomes a participant in the narrative form ...."

Die metode om die verteller aan te hoor waar hy op verskillende "vlakke" met sy leser praat is, soos gemeld, 'n bepaalde toepassing van "narrative point of view" deur Boris Uspensky. Hierdie "vlakke" is sekerlik, soos Uspensky (1973: 7) self sê, arbitrêr gekies - daar kan inderdaad meer of selfs ander kategorieë as die ideologiese, fraseologiese, psigologiese en tyds- en topografiese "vlakke" wees waarvolgens toegang verkry kan word tot die verteller, sy vertelwêreld en die implisiete leser. Dié bepaalde toepassing van die vertellersperspektief-analise se metodologiese bruikbaarheid word egter in 'n groot mate deur die sistematiese en logiese stappe ("vlak"-gewys) verhoog. Die ondersoeke na die onderskeie "vlakke" in die teks kan ook as wedersydse kontrole dien. Die aanvaarding in wyer vakwetenskaplike kring van die vertellersperspektief-analise as eksegetiese metode word onses insiens bepaal deur enersyds bogenoemde kontroleerbaarheid en andersyds deur die sukses waarmee dit reg laat geskied aan die baie belangrike, hoewel problematiese, verhouding in taalgebruik tussen "vorm" en "inhoud", oftewel "tegniek" en "idee".

Die feit dat die studie van die metode van uitleg van die Nuwe Testament in sekere opsigte 'n krisis ervaar, het deurgewerk na die ondersoek van die teologie van die Nuwe Testament. Wat die teologie van die evangelies betref, word hedendaags algemeen aanvaar dat elke evangelis 'n "teoloog" in eie reg is. Die spekulatiewe en positivistiese aard van die tradisionele historiese kritiek het egter die probleem meegebring dat eksegete se identifisering van die inhoud van een en dieselfde evangelie uiteenlopend is. Die gevolg hiervan is dat daar, wat die vier evangelies betref, nêrens konsensus in verband met die teologiese sentrum daarvan gerapporteer kan word nie. Met behulp van die vertellersperspektief-analise kan die intrinsieke ideologie (teologie) van elke evangelie doeltreffender omskryf word. Dit is 'n belangrike, voortwaartse stap in die studie van die teologie van die Nuwe Testament. 
Net so belangrik as die besef van die winste, is die insig in die beperkte moontlikhede van die vertellersperspektief-analise. Die bepaling van die historiese, godsdienstige, sosiologiese en ekonomiese konteks waarteen die evangelies sinkronies gelees moet word, is nie deel van dié metode nie. Die historiese agtergrond-identifisering is noodsaaklik, maar dit is 'n studie op sy eie. Die vertellersperspektief-analise is ewe-eens nie geïnteresseerd in die linguistiese oppervlaktestruktuur nie. $\mathrm{Hy}$ is ook nie geinteresseerd in die struktureel-patroonmatigheid van die universeel-argetipiese wat in die dieptestruktuur van die teks geleë is nie. Indien 'n eksegeet hierdie twee aspekte van taalondersoek in die oog het, sou die SuidAfrikaanse kolonanalise en die Franse aktante-analise, respektiewelik, vir hom van hulp wees. Insgelyks sal 'n eksegeet hom van 'n ander metode as die vertellersperspektief-analise moet laat bedien, as hy die wordingsgeskiedenis van die evangelies wil bestudeer. Só 'n ondersoek sal hoofsaaklik histories-krities van aard moet wees. Wat die vertelemente in verteltekste soos die evangelies betref, sal 'n eksegeet egter nie foutmaak as hy die vertellersperspektief-analise sou inspan om dié elemente te ontleed nie.

\section{LITERATUURVERWYSINGS}

Abrams, MH 1971. A glossary of literary terms. 3rd Edition. New York: Holt.

Blok, W 1960. Verhaal en lezer. Groningen: Wolters.

Butcher, SH 1951. Aristotle's theory of poetry and fine art. With a critical text and translation of the Poetics. 4th Edition. New York: Dover.

Combrink, HJB 1982. The structure of the Gospel of Matthew as narrative. Ongepubliseerde voordrag, Universiteit van Cambridge. (Vir publikasie in Tyndale Bulletin).

Du Rand, JA 1982. Die struktuur van die Christologie van Johannes. Metodologiese oorwegings. Bloemfontein: Universiteit van die Oranje-Vrystaat. (Professorale intreerede).

Fowler, $R$ 1982. How to see through language, perspective in fiction. Poetics 11, 213-35.

Hawkes, T 1977. Structuralism and semiotics. London: Methuen.

Kenney, W 1966. How to analyse fiction. New York: Monarch.

Lämmert, E 1972. Bauformen des Erzählens. 5. Auflage. Stuttgart: Metzlersche Verlagsbuchhandlung.

Lanser, SS 1981. The narrative act. Point of view in prose fiction. Princeton: University Press.

Petersen, NR 1978 a. Literary criticism for New Testament critics. Philadelphia: Fortress.

Petersen, NR 1978b. "Point of view" in Mark's narrative. Semeia 12, 97-121.

Petersen, NR 1980. Literary criticism in biblical studies, in RA Spencer (ed). Orientation by disorientation. Studies in literary criticism and biblical literary criticism. (Presented in honor of William A Beardslee). Pittsburgh: Pickwick, 25-50.

Polzin, RM 1980. Literary and historical criticism of the Bible: A crisis in scholarship, in RA Spencer (ed). Orientation by disorientation. Studies in literary criticism and biblical literary ciriticism. (Presented in honor of William A Beardslee). Pittsburgh: Pickwick, 99-114.

Propp, V 1978. Structure and history in the study of the fairy tale. Semeia 10, 57-83. (Translated by HT McElwain).

Resseguie, JL 1982. Point of view in the central section of Luke (9:51-19:44). Joumal of the Evangelical Theological Society 25, 41-7. 
Rhoads, D 1982. Narrative criticism and the Gospel of Mark. Joumal of the American Academy of Religion 50, 411-34.

Tucker, GM 1975. Editor's foreword, in E Krentz. The historical-critical method. Philadelphia: Fortress, $v-v i$.

Uspensky, B 1973. A poetics of composition. The structure of the artistic text and typology of a compositional form. (Translated by S Wittig). Berkely: University of California Press.

Van Aarde, AG 1982a. Matthew's portrayal of the disciples and the structure of $\mathrm{Mt}$ 13:53-17:27, in Structure and meaning in Matthew 14-28. Stellenbosch: NTSSA, 21-34. (Neotestamentica 16).

Van Aarde, AG 1982b. God met ons. Dié teologiese perspektief van die Matteusevangelie. Pretoria: Universiteit van Pretoria. (Ongepubliseerde DD proefskrif).

Vandermoere, H 1976. The study of the novel. A structural approach. Leuven: Acco.

Vorster, WS 1980. Die evangelie volgens Markus: inleiding en teologie, in AB du Toit (red). Handleiding by die Nuwe Testament. IV. Die Sinoptiese Evangelies en Handelinge: inleiding en teologie. Pretoria: NG Kerkboekhandel, 109-55.

Vorster, WS 1982. Meaning and reference: the parables of Jesus in Mark 4. Ongepubliseerde voordrag, Colloquium Biblicum Lovaniense. 